\title{
Keterlibatan Perempuan Dalam Sektor Pertanian Untuk Menunjang Kesejahteraan Keluarga Menurut Perspektif Feminisme (Studi Kasus Di Desa Songan, Bangli, Bali)
}

\author{
Ni Luh Sinta Yani ${ }^{*}$, Luh Indrayani²
}

1,2Universitas Pendidikan Ganesha, Singaraja-Indonesia

\section{A R T I C L E I N F O}

Article history:

Received March, 132021

Received in revised form

November, 202021

Accepted November, 22

2021

Available online December

252021

Kata Kunci:

Petani perempuan,

keterlibatan, feminisme

Keywords:

Women farmer, involment,

feminisme

\begin{abstract}
A B S T R A K
Penelitian ini bertujuan untuk mendeskripsikan faktor yang menyebabkan perempuan Desa Songan terlibat dalam sektor pertanian, mendeskripsikan keterlibatan perempuan terhadap sektor pertanian untuk menunjang kesejahteraan keluarga, dan mendeskripsikan pandangan feminisme terhadap petani perempuan di Desa Songan. Penelitian ini adalah menggunakan pendekatan kualitatif dengan metode studi kasus. Informasi yang dikumpulkan menggunakan triangulasi data, yaitu observasi partisipatif, wawancara mendalam, dan studi dokumentasi. Data diuji validitasnya menggunakan triangulasi sumber. Hasil penelitian ini adalah terdapat empat faktor yang menyebabkan perempuan Desa Songan terlibat dalam sektor pertanian, yaitu faktor geografis, faktor desakan ekonomi, faktor kebiasaan, dan faktor pendidikan. Perempuan Desa Songan memiliki dua peran yang sangat penting dalam meningkatkan kesejahteraan keluarga, yaitu berperan di ladang pertanian, dan di rumah tangga. Nilainilai feminisme secara tidak langsung sudah diterapkan di Desa Songan, karena perempuan memiliki kesempatan yang sama seperti laki-laki.
\end{abstract}

This research aims to describe the factors that cause Songan's women to be involved in the agricultural sector, describe the involvement of women in the agricultural sector to support family welfare, and describe the feminist view of women farmers in Songan Village. This research used a qualitative approach with a case study method. The information collected using data triangulation, namely participatory observation, in-depth interviews, and documentation studies. The validity of the data was tested using triangulation of sources. The results and discussion showed that there are four factors that cause Songan's women to be involved in the agricultural sector, namely geographic factors, economic pressure factors, habit factors, and educational factors. Songan's women have two very important roles in improving family welfare, namely playing a role in agriculture and in the household. Feminist values have been applied indirectly in Songan village because women have the same opportunities as men.

*Corresponding author.

E-mail : niluhsintayani30@undiksha.ac.id (Ni Luh Sinta Yani) 


\section{Pendahuluan}

Bali menjadi salah satu wilayah yang kental terhadap budaya patriarki. Masyarakat yang menganut budaya patriarki menyebabkan kaum perempuan yang menjadi subordinat laki-laki dan termarginalkan menjadi miskin (Arjani, 2007). Kemiskinan yang dialami oleh perempuan Bali karena mereka hanya diberikan ruang di wilayah domestik atau ranah rumah tangga. Sebenarnya, perempuan menjadi kelas kedua karena konstruk sosial yang mengharuskannya agar memiliki ketergantungan secara ekonomi terhadap laki-laki (Safira, 2019)

Seiring dengan perkembangan jaman, perempuan Bali semakin sadar untuk bisa setara dengan lakilaki dan ingin melawan ketertindasan yang dialaminya yaitu dengan turut serta menjadi bagian dari pencari nafkah tanpa meninggalkan tugasnya di rumah tangga. Perempuan Bali masuk ke dalam ranah ekonomi, bertujuan untuk meningkatkan kesejahteraan dan meringankan beban ekonomi kepala keluarga (Indrayani \& Musmini, 2020). Kemandirian perempuan Bali secara ekonomi tercermin dari keterlibatan perempuan Bali terhadap sektor pertanian di Bali.

Desa Songan menjadi salah satu penghasil pertanian di Bali, tepatnya berada di Kecamatan Kintamani, Bangli. Secara administratif, Desa Songan dibagi menjadi dua yaitu Desa Songan A dan Desa Songan B. Wilayah yang mendukung untuk melakukan kegiatan bercocok tanam, menjadi faktor sebagian besar masyarakat Desa Songan berprofesi sebagai petani. Data statistik menyebutkan bahwa 38,92\% penduduk desa Songan A bekerja sebagai seorang petani dan $44.28 \%$ penduduk desa Songan B juga sebagai seorang petani. Dari data statistik disebutkan pula bahwa, perempuan Songan mendominasi ladang pencaharian sebagai petani. Persentase perbandingan antara petani perempuan dengan petani laki-laki di Songan A adalah 19, 16\% (persentase laki-laki) dan 19,76\% (persentase perempuan). Sedangkan perbandingan persentase antara petani laki-laki dan petani perempuan di Songan B adalah 21,19\% dan 23,09\% (data statistik, 2019). Dari data statistik, dapat dilihat persentase jumlah petani perempuan Desa Songan lebih banyak dibandingkan dengan persentase jumlah petani laki-laki. Artinya, perempuan Songan diberikan kedudukan yang sama dalam bekerja di ladang pertanian yang notabenenya adalah pekerjaan berat. Perempuan tidak hanya dibebankan pada tugas rumah tangga, tetapi diberikan kesempatan untuk berekspresi di dunia kerja dan diberikan hak-hak yang berkaitan dengan keterlibatan dominasi di dunia kerja. Tentu hal ini sejalan dengan penghormatan gender yang berkaitan dengan kesetaraan kesempatan di lingkungan kerja (Fadilah, 2018). Perempuan Desa Songan lebih agresif dalam upaya pemenuhan kebutuhan dalam upaya membantu perekonomian keluarga.

Masyarakat Desa Songan memberikan penguatan emansipasi petani perempuan di dunia kerja dengan memberikan ruang yang sama dengan laki-laki. Namun, ada beberapa koridor yang belum dipenuhi, sehingga kesetaraan antara perempuan dan laki-laki di Desa Songan belum bisa dikatakan sempurna. Dari observasi dan wawancara yang dilakukan oleh peneliti, di Desa Songan seorang istri menjadi tulang punggung utama keluarga, karena banyak suami mereka yang tidak bekerja. Namun, keutamaan mereka mencari nafkah masih dilabeli dengan stigma "pencari nafkah tambahan", bukan sebagai "pencari nafkah utama". Di sisi lain, upah yang didapatkan petani perempuan tidak setara dengan petani laki-laki. Pekerjaan petani perempuan hanya diupah sebesar Rp.100.000, sedangkan petani laki-laki diberikan upah sebesar Rp.120.000, walaupun hasil kerja mereka sama. Badan Pusat Statistik Provinsi Bali (2019) mencatat bahwa, kontribusi pendapatan perempuan di Bangli hanya 38,19\% terhadap perekonomian di Kabupaten Bangli. Ada tiga hal yang menyebabkan kontribusi pendapatan perempuan lebih rendah dibandingkan laki-laki, yaitu (1) perempuan memiliki kewajiban pokok mengurus pekerjaan rumah tangga, sehingga hanya bisa mengerjakan tugas di arena publik ketika pekerjaan rumah tangga telah selesai. (2) Suami dianggap sebagai kepala keluarga dan menjadi pencari nafkah utama, dan istri hanya diam di rumah dan mengurus rumah tangga. Jadi, ketika istri atau perempuan melakukan suatu pekerjaan yang bertujuan untuk memenuhi kebutuhan, tidak terlalu berdampak terhadap kesejahteraan keluarga(Astuti, 2011).

Jika ditinjau dari perspektif feminisme, perempuan sebenarnya memiliki peran yang sangat besar dalam upaya peningkatan kesejahteraan keluarga. Gerakan feminisme yang dilakukan oleh perempuan terutama yang berstatus ibu rumah tangga adalah dengan membentuk suatu institusi/organisasi untuk menampung kreativitas mereka dalam rangka meningkatkan kesejahteraan keluarga. Perempuan berupaya untuk bekerja ketika pendapatan suami kurang atau bahkan tidak mendapatkan nafkah ekonomi dari suami (Anwar, 2013)

Kesetaraan gender dapat dilihat dari ranah 3 aspek. Aspek yang pertama yaitu, perempuan adalah bagian dari ciptaan Tuhan sama seperti laki-laki. Segala bentuk ciptaan Tuhan memiliki kedudukan yang sama. Aspek yang kedua adalah masalah konsep kepemimpinan. Perempuan juga memiliki hak untuk mejadi seorang pemimpin baik pemimpin di lingkungan domestik maupun lingkungan publik. Aspek yang 
ketiga adalah aspek ekonomi. Perempuan memiliki kesempatan yang sama di bidang ekonomi sehingga perempuan yang memiliki julukan tulang rusuk bergeser menjadi tulang punggung (Fadilah, 2018)

Kesejahteraan keluarga tidak dilihat dari seberapa besar penghasilan suaminya, akan tetapi dilihat dari bagaimana istri memanajemen pendapatan untuk kesejahteraan keluarga (Hanum, 2017). Di samping itu, gerakan feminisme mengajarkan bahwa, seorang istri harus memiliki daya kreativitas yang tinggi untuk memanfaatkan kesempatan yang ada, jika memang pendapatan suami tidak mencukupi. Ibu rumah tangga yang memiliki peran ganda disebabkan karena terhimpitnya faktor ekonomi, seperti banyaknya tanggungan keluarga dan untuk memenuhi biaya pendidikan anak-anaknya. Namun, meskipun memegang peran ganda, ibu rumah tangga mampu menjalankan fungsi keluarga dengan baik.

Hasil penelitian dari Indrayani dan Musmini (2020), mengungkapkan bahwa perempuan yang turut terlibat dalam kegiatan ekonomi akan membantu memenuhi kebutuhan keluarga sebagai langkah awal untuk melancarkan segala kegiatan lain yang lebih beragam. Keterlibatan perempuan dalam kegiatan ekonomi dapat meningkatkan status sosial ekonomi dalam keluarga. Tingkat status sosial ekonomi dalam keluarga yang memadai berperan dalam perkembangan anak-anak. Anak-anak dengan tingkat ekonomi keluarga yang tinggi akan memperoleh kesempatan yang lebih luas untuk menggunakan uang dalam memenuhi kebutuhan.

Jackson dan Jakie menjelaskan tujuan dari feminisme adalah, pertama menyediakan informasi dan analisis mengenai perempuan. Kedua, mengupayakan perubahan sosial dan menghilangkan ketidaksetaraan gender. Ketiga, menjadikan diri sebagai sebuah kritik terhadap ilmu pengetahuan yang ada. Keempat, memperlihatkan bagaimana perpektif kaum perempuan mengenai ilmu pengetahuan yang belum terlihat pada ilmu pengetahuan sebelumnya (Lubis, 2015).

Feminisme mengalami banyak penolakan terutama di Indonesia. Safira (2019) mengungkapkan bahwa laki-laki sudah dibiasakan dengan kenyamanan dalam membebankan peran domestik kepada perempuan. Para laki-laki memakai segala cara agar tidak kehilangan kenyamanan itu. Laki-laki menggunakan segala propaganda bahwa feminisme berasal dari Barat, ajaran setan, tidak cocok dengan ajaran agama tertentu, serta merusak ketahanan keluarga. Padahal dogma yang diterapkan kepada perempuan tidak diterapkan pada laki-laki. Doktrin yang diberikan kepada perempuan menyebabkan pemikiran perempuan tidak bisa berkembang karena lingkungan yang mengonstruksikan pikirannya agar tetap stagnansi dan tidak melebihi laki-laki.

Feminisme sebenarnya mengajarkan adanya keseimbangan antara hak perempuan dan hak laki-laki. Perempuan diberikan hak kebebasan sebagai perempuan, seperti hak untuk berpendidikan, hak memperoleh pekerjaan yang layak, hak untuk mengembangkan diri dan meraih cita-cita. Hak tersebut wajib untuk dilindungi dalam konstitusi negara tanpa membedakan jenis kelamin (Djoharwinarlien, 2012). Perempuan membutuhkan jaminan negara untuk keluar dari stagnansi yang diciptakan oleh mitos. Negara dapat membantu perjuangan perempuan dengan cara menciptakan regulasi untuk melindungi perempuan. Regulasi harus menjamin perempuan mendapatkan fasilitas saat bekerja di sektor publik, mendapatkan hak memperoleh pendidikan, dan penghidupan yang layak. Negara juga harus membuat lembaga yang bersifat independen yang bisa mengontrol implementasi dari peraturan tersebut.

Berdasarkan dari uraian di atas, maka tujuan dari penelitian ini adalah (1) mendeskripsikan faktor yang menyebabkan perempuan Desa Songan terlibat dalam sektor pertanian, (2) mendeskripsikan keterlibatan perempuan terhadap sektor pertanian untuk menunjang kesejahteraan keluarga, dan (3) mendeskripsikan pandangan feminisme terhadap petani perempuan di Desa Songan.

\section{Metode}

Pendekatan yang digunakan pada penelitian ini adalah pendekatan kualitatif. Penelitian kualitatif bertujuan untuk mengungkapkan data secara kualitatif dan disajikan secara naratif. Cakupan dari data kualitatif antara lain yaitu (a) deskripsi yang mendetail tentang situasi, kegiatan, atau peristiwa maupun fenomena tertentu (b) pendapat langsung dari orang-orang yang telah berpengalaman, pandangannya, sikapnya, kepercayaan, serta jalan pikiranya (c) cuplikan dari dokumen (d) deskripsi yang mendetail tentang sikap dan tingkah laku seseorang (Yusuf, 2014).

Metode yang dipergunakan untuk menjelaskan penelitian Keterlibatan Perempuan dalam Sektor Pertanian untuk Menunjang Kesejahteraan Keluarga Menurut Perspektif Feminisme (Studi Kasus di Desa Songan, Bangli, Bali) adalah Study Case. Tujuan menggunakan metode studi kasus pada penelitian ini adalah untuk mengkaji secara dalam budaya patriarki yang berkembang di masyarakat Bali yang sangat memarginalisasi kaum perempuan. Ketidaksetaraan perlakuan akibat dari perbedaan gender ini, akan dikupas dalam bentuk kajian feminisme. Kajian ini bisa menjadi bahan pertimbangan untuk memperjuangkan hak-hak perempuan dalam kehidupan bermasyarakat. 
Penelitian ini berlokasi di Desa Songan, Kecamatan Kintamani, Kabupaten Bangli Bali. Lokasi ini dipilih sebagai tempat penelitian karena kuantitas petani perempuan di Desa Songan lebih banyak daripada petani laki-laki dibandingkan dengan daerah-daerah lainnya. Perempuan yang dianggap tidak berdaya akibat konstruksi dari budaya patriarki, namun ditampikkan oleh para petani perempuan di Songan. Mereka mampu melakukan pekerjaan berat (bertani) dan sebanding dengan pekerjaan yang dilakukan oleh laki-laki. Namun tetap saja mereka tidak diberikan suatu keadilan dalam hal pemberian upah. Gelar bahwa perempuan makhluk lemah masih dikalungkan kepada mereka sehingga mereka tidak mendapatkan hak yang setara dengan laki-laki. Selain harus turut memenuhi kebutuhan keluarga, petani perempuan di Songan juga harus dibebankan tugas di ranah privat (rumah tangga) dan ranah publik (sosial bermasyarakat). Sehingga hal ini sangat menarik untuk peneliti mengambil lokasi penelitian di Desa Songan.

Untuk memperoleh data mengenai kondisi petani perempuan di Desa Songan, peneliti melakukan observasi untuk menyelidiki tingkah laku nonverbal. Peneliti ikut berpatisipasi dalam kegiatan bertani dan kegiatan lainnya yang dilakukan oleh petani perempuan di Desa Songan dan mengamati kondisi lingkungan yang mempengaruhi fisik dan psikologi para petani perempuan di desa Songan. Selain itu, data primer juga diperoleh dengan cara melakukan wawancara mendalam terhadap petani perempuan. Hal ini dilakukan untuk menyelami kondisi yang sesungguhnya terjadi pada petani perempuan, seperti perasaan ketika dibebankan banyak tugas, perjuangan dalam menyibak peran, dan pertanyaan-pertanyaan lainnya yang berkaitan dengan rumusan masalah. Wawancara mendalam juga akan dilakukan dengan para pemimpin di Desa Songan, seperti kepala desa. Wawancara ini dilakukan untuk mengetahui adat dan budaya di Desa Songan yang sangat mempengaruhi kondisi sosial bermasyarakatnya. Dari wawancara mendalam kepada kepala desa peneliti dapat mempertimbangkan dalam mencari jalan untuk mengupayakan kesetaraan gender agar tidak keluar jalur dari adat dan tradisi yang dianut di Desa Songan serta menyadari tantangantantangan dalam memperjuangkan kesetaraan gender. (2) Data sekunder, yaitu data yang digunakan untuk menunjang data primer. Dalam penelitian ini, peneliti juga menggunakan sumber data sekunder untuk mendukung penelitian ini. Adapun sumber data sekunder dari penelitian ini adalah (a) Profil Desa Songan Kecamatan Kintamani (b) jurnal-jurnal penelitian.

Informan yang berkontribusi dalam memberikan informasi pada penelitian ini adalah para petani perempuan Desa Songan A dan Songan B, Kecamatan Kintamani. Sebelum memasuki situasi sosial, peneliti menentukan sumber data yang akan dijadikan sebagai subyek yang diteliti dalam konteks sosial budaya. Pada penelitian ini, peneliti metode pengumpulan data yang digunakan adalah teknik purposive sampling. Pada konteks penelitian, penentuan sampel menggunakan purposive dilandai dengan pertimbangan tertentu terlebih dahulu (Yusuf, 2016). Pada penelitian ini, informan yang digunakan adalah petani perempuan di Desa Songan A dan Desa Songan B, Kecamatan Kintamani dan klian adat dan kepala desa Songan A dan Songan B. Adapun karakteristik dari petani perempuan yang akan dijadikan informan yaitu: (1) petani perempuan yang sudah lama menjadi seorang petani yaitu lebih dari lima tahun sehingga pengalaman dalam pertanian sudah banyak, (2) petani perempuan yang sudah menikah, sehingga bisa mengetahui bagaimana perannya dalam rumah tangga dan meningkatkan kesejahteraan keluarga.

Penelitian ini menggunakan teknik pengambilan data dengan triangulasi, yaitu observasi partisipatif, wawancara mendalam, dan studi dokumentasi. Data yang sudah diperoleh kemudian diuji keabsahannya dengan menggunakan triangulasi sumber, yaitu dengan membandingkan informasi yang diperoleh dengan informan/narasumber yang berbeda. Proses analisis data yaitu dimulai dengan mengumpulkan data, mereduksi data, menyajikan data, dan verifikasi.

\section{Hasil dan Pembahasan \\ a. Hasil}

Data BPS menunjukan bahwa perempuan Desa Songan mendominasi sebagai petani. Persentase perbandingan antara petani perempuan dengan petani laki-laki di Songan A adalah 19, 16\% (persentase laki-laki) dan 19,76\% (persentase perempuan). Sedangkan perbandingan persentase antara petani lakilaki dan petani perempuan di Songan B adalah 21,19\% dan 23,09\% (data statistik, 2019). Penuturan dari Bapak I Putu Eka Pratama selaku Plt perbekel Desa Songan B pada tanggal 7 Februari 2021 yaitu:

“....perempuan Desa Songan memang lebih banyak menjadi seorang petani dan kegiatan sehariharinya selalu diselingi dengan kegiatan bertani. Sehingga data statistik bisa menunjukan kalau petani perempuan lebih banyak dibandingkan dengan petani laki-laki."

Berdasarkan data yang diperoleh peneliti, terdapat empat faktor utama perempuan Songan terlibat dalam sektor pertanian, yaitu faktor geografis, faktor desakan ekonomi, faktor kebiasaan, dan faktor pendidikan. 
Bersumber dari hasil wawancara pada tanggal 7 Februari 2021 yang dilakukan dengan Plt perbekel Desa Songan B, yang mengungkapkan bahwa:

"....Desa Songan memiliki tanah yang subur sehingga bisa ditanami berbagai jenis tanaman. Desa Songan juga dekat dengan Danau Batur sehingga sangat mudah memperoleh air untuk tanaman. Selain itu, wilayah desa Songan juga pernah terkena lahar dari Gunung Batur, dan sekarang berdampak pada kesuburan tanahnya".

Wawancara juga dilakukan dengan Ibu Kadek Priandani sebagai salah satu petani perempuan di Desa Songan yang sudah menjadi petani semenjak 10 tahun. Beliau mengungkapkan bahwa:

"saya menjadi petani karena memiliki ladang pertanian yang tanahnya sangat subur. Di ladang, saya biasa menanam bawang, tomat, dan sayuran. Tanaman -tanaman tersebut mampu tumbuh dengan baik di ladang saya. Hasil pertaniannya juga sangat baik, sehingga bisa saya jual ke luar daerah dan digunakan untuk kebutuhan sendiri".

Perempuan Songan ikut terlibat dalam pertanian karena turut serta membantu memenuhi kebutuhan keluarga. Selain itu, ada beberapa dari mereka yang bekerja di ladang pertanian karena menjadi tulang punggung keluarganya. Informasi yang diperoleh peneliti pada tanggal 8 Februari 2021 dari petani perempuan yang bernama Ibu Ni Nyoman Wage dan sudah bekerja menjadi seorang petani selama 30 tahun, sebagai berikut.

"Saya menjadi petani sudah selama 30 tahun. Saya bekerja di ladang milik orang lain. Saya bekerja untuk membantu suami saya yang juga bekerja di ladang ini. Pekerjaan bertani akan lebih cepat selesai jika dikerjakan bersama -sama. Saya ikut bekerja agar bisa membantu suami memenuhi kebutuhan hidup."

Selain itu, informasi yang hampir serupa juga peneliti peroleh dari informan petani perempuan yang bernama Ibu Ni Wayan Seriasih yang sudah menjadi petani semenjak berusia 15 tahun. Beliau mengungkapkan bahwa:

"bertani sudah menjadi pekerjaan utama di Desa Songan. Kalau suaminya seorang petani, pasti istrinya juga ikut bertani. Istri akan membantu pekerjaan suami di ladang pertanian agar hasil yang diperoleh bisa lebih banyak. Saya juga ikut bertanggungjawab dalam memenuhi kebutuhan keluarga walaupun saya memiliki tugas di rumah tangga".

Perempuan Songan bekerja di ladang pertanian karena sudah dididik oleh orang tuanya untuk menjadi seorang petani. Secara turun temurun, masyarakat Songan sudah menjadi seorang petani dan mengandalkan kehidupannya di ladang pertanian. Semenjak kecil, anak-anak sudah sangat akrab dengan tanaman yang biasa ditanam di tanah Desa Songan dan diajarkan bagaimana mengelola ladang. Ini yang menyebabkan mereka sudah terbiasa dengan ladang pertanian. Dari hasil wawancara pada tanggal 9 Februari 2021 kepada Ibu Ni Komang Suarniti, mengatakan bahwa:

"saya menjadi petani karena itu pekerjaan yang saya lakukan sejak kecil. Orang tua dan kakek nenek sudah mengajarkan saya untuk bertani. Dari kecil saya sudah membantu orang tua untuk bekerja di ladang. Jadi saya sudah tahu bagaimana cara mengelola ladang pertanian. Jadi ketika sudah menikah seperti sekarang, saya tetap bekerja di ladang pertanian untuk membantu suami yang kebetulan juga seorang petani untuk memenuhi kebutuhan hidup"

Hal yang serupa juga didapatkan penulis dari Ibu Ni Kadek Sukarini, yang mengungkapkan bahwa:

"bertani sudah menjadi kebiasaan saya sejak kecil. Saya dulu bersekolah sambil membantu orang tua bertani di ladang. Orang tua sudah mengajarkan saya cara bertani. Orang tua saya juga diajarkan oleh nenek kakek saya, dan sekarang saya juga mengajarkannya kepada anak-anak saya. Menjadi petani sangat bermanfaat untuk saya, selain untuk membantu kebutuhan keluarga, bertani bisa saya lakukan sambil menjadi ibu rumah tangga".

Faktor lainnya yang menyebabkan perempuan menjadi seorang petani adalah faktor pendidikan. Rata-rata petani perempuan mengenyam pendidikan sampai dengan tingkat Sekolah Dasar dan bahkan ada yang tidak mengenyam pendidikan sama sekali. Mereka memilih menjadi petani, karena mereka tidak memiliki ijazah untuk digunakan melamar kerja di tempat tertentu. Menurut penuturan dari Ni Cening salah seorang petani perempuan yang sudah bertani semenjak usia 10 tahun, mengungkapkan bahwa:

"saya tidak pernah sekolah, jadi pekerjaan yang saya bisa lakukan hanya bertani. Dari umur 10 tahun saya sudah bekerja menjadi petani dan usia saya sekarang sudah 55 tahun. Makanya saya sekarang buta huruf, dan tidak bisa bekerja selain bertani".

Perempuan Songan memiliki peran yang tinggi terhadap sektor pertanian dengan tujuan untuk menunjang kesejahteraan keluarga. Hasil informasi yang diperoleh penulis dari Plt perbekel Desa Songan A pada tanggal 7 Februari 2021, sebagai berikut.

"petani perempuan di Desa Songan memiliki keterlibatan yang tinggi dalam bidang pertanian baik yang memiliki ladang ataupun yang bekerja di ladang orang lain. Walaupun ada beberapa dari mereka yang sudah menjadi pegawai, tapi mereka tetap menyempatkan waktu untuk bertani. Pekerjaan yang diambil petani perempuan dan petani laki-laki hampir sama". 
Sebagai perempuan memang tidak pernah lepas dari tugas domestik yang harus dikerjakan. Tapi perempuan juga memiliki tanggungjawab untuk ikut serta berupaya meningkatkan kesejahteraan keluarganya. Petani perempuan Desa Songan tidak hanya bekerja di ladang pertanian, namun juga memiliki peran di rumah tangga untuk menunjang kesejahteraan keluarga. Berikut peran petani perempuan Desa Songan di ladang pertanian dan di rumah tangga.

Perempuan Songan memiliki posisi pencari nafkah baik sebagai pencari nafkah pokok maupun pencari nafkah tambahan. Perempuan Songan mampu memanfaatkan peluang yang ada untuk menghasilkan pendapatan. Mereka mengelola sumber daya alam yang tersedia untuk memenuhi kebutuhan hidup dan menunjang kesejahteraan keluarganya. Menurut penuturan dari Ibu Ni Wayan Sarmi pada tanggal 9 Februari 2021, yaitu:

"saya bekerja ikut dengan suami di ladang milik orang lain dan mendapatkan upah dari sana. Upah ini saya pakai untuk bantu suami memenuhi kebutuhan keluarga. Saya melakukan semua pekerjaan pertanian sama seperti yang suami saya kerjakan".

Menurut informasi dari dari Bapak I Nengah Sentana pada tanggal 7 Februari 2021 sebagai berikut.

"perempuan Songan memiliki kontribusi yang tinggi dalam meningkatkan kualitas pertanian. Mereka begitu cekatan bekerja dan pekerjaannya lebih rapi daripada laki-laki. Perempuan juga mampu menciptakan peluang-peluang dalam pertanian, seperti mencoba menanami ladang dengan tanaman-tanaman baru. Sehingga hasil pertanian bisa lebih beragam. Saya juga melihat bahwa perempuan itu bekerja dengan hati dan perasaan, sehingga kualitas pertanian bisa lebih baik dan mampu memilah hasil-hasil pertanian yang layak dijual. Perempuan Songan lebih responsif terhadap kondisi keluarganya. Jika mereka melihat suaminya belum mampu mencukupi kebutuhan keluarga, maka mereka turut bekerja, bahkan ikut juga meburuh di ladang milik orang lain. Mereka juga ikut berjualan hasil pertanian ke luar daerah untuk mendapatkan penghasilan tambahan".

Informasi yang peneliti dapatkan dari Ibu Kadek Priandani sebagai salah satu petani perempuan, pada tanggal 9 Februari 2021 sebagai berikut.

"bertani sudah menjadi salah satu hobi buat saya. Pekerjaan yang sudah menjadi hobi dan itu bisa menghasilkan uang maka kita menjalaninya pasti senang. Rasa senang yang dilakukan selama bekerja yang mungkin menyebabkan hasil pertanian menjadi bagus dan menurut kepercayaan dan tradisi di sini, sebelum hasil pertanian dijual, kami mengadakan upacara tertentu memohon kepada Dewi Danu agar hasil pertanian ini bisa laku terjual. Saya juga senang karena uang yang saya dapatkan bisa saya gunakan untuk memenuhi kebutuhan keluarga, menyekolahkan anak-anak, dan membelikan keinginan anak".

Rasa tanggung jawab terhadap keluarganya membuat petani perempuan Desa Songan ikut bekerja keras. Keterampilan yang mereka miliki dimanfaatkan sebaik mungkin untuk mempertahankan hidup. Kualitas hasil pertanian yang bagus juga akibat dari campur tangan petani perempuan yang bekerja dengan cekatan.

Perempuan Songan selain berperan sebagai seorang petani, mereka tidak pernah lepas dengan tanggungjawabnya sebagai seorang ibu rumah tangga. Tugas rumah tangga yang biasa dilakukan oleh petani perempuan Desa Songan hampir sama dengan tugas ibu rumah tangga lainnya, seperti memasak, membersihkan rumah, mengurus anak, dan mencuci. Petani perempuan di sana mampu mengelola waktunya dengan baik. Pekerjaan rumah tangga, dilaksanakan secara bersama-sama oleh anggota keluarga lainnya. Suami juga turut membantu, karena petani perempuan juga membantu dalam bekerja untuk memenuhi kebutuhan keluarga. Menurut penuturan dari Ibu Ni Wayan Sarmi pada tanggal 9 Februari 2021, yang menceritakan bahwa:

"pekerjaan di rumah tangga biasanya dibantu oleh suami dan anak-anak saya. Sehingga saya bisa membagi waktu untuk bekerja di ladang pertanian. Pagi sebelum ke ladang saya memasak dulu, suami dan anak-anak membantu membersihkan rumah. Kalau mencuci pakaian, itu sudah masing-masing. Anak-anak saya juga sudah besar, jadi sudah bisa mencuci sendiri. Saya hanya mencuci baju saya dan di rumah. Kalau urusan ngayah di pura itu tidak wajib, karena suami saya bukan bagian dari prajuru adat. Jadi ke pura kalau mau sembahyang. Kalau mau buat banten juga dibantu oleh anak-anak".

Berbicara tentang feminisme, pembahasannya tidak akan jauh-jauh dari kesetaraan gender. Petani perempuan Desa Songan diberikan ruang untuk turut bekerja. Stereotif gender pada budaya patriarki yang mengharuskan perempuan berada di ranah domestik dan laki-laki berada di ranah publik sudah tidak diperdebatkan oleh masyarakat Desa Songan. Tingkat pendapatan petani terutama yang bekerja di ladang milik orang lain masih tergolong rendah dan kadang-kadang mengalami gagal panen sehingga pendapatannya otomatis akan mengalami penurunan. Perempuan memiliki rasa tanggung jawab untuk ikut serta bekerja agar menunjang perekonomian keluarga, dan hal tersebut mendapatkan dukungan dari suami dan keluarga.

Petani perempuan di Desa Songan juga diberikan kesempatan untuk ikut serta dalam pelatihanpelatihan tentang pertanian. Penyuluh Pertanian Lapangan sering mengadakan pelatihan tentang seluk 
beluk bertani. Petani perempuan juga dilibatkan dalam pelatihan-pelatihan tersebut. Menurut penuturan dari Ibu Kadek Priandani pada tanggal 9 Februari 2021, yaitu:

"saya dan petani perempuan di sini pernah mengikuti pelatihan pertanian yang diadakan oleh dinas pertanian. Pelatihan itu tidak khusus untuk perempuan, tapi untuk semua petani. Waktu itu saya diajarkan cara memilih bibit yang bagus, cara menanam yang baik, dan cara mengelola hasil panen agar berkualitas dan bisa dijual di hotel-hotel".

Keikutsertaan petani perempuan dalam pelatihan-pelatihan tersebut, mengartikan bahwa masyarakat Songan sudah berpikiran terbuka terhadap perempuan dengan memberikan peluang untuk perempuan mengembangkan dirinya. Keterampilan yang mereka miliki akan semakin baik, walaupun banyak dari mereka tidak mengenyam pendidikan formal. Pelatihan ini berdampak pada kualitas hasil pertanian yang semakin meningkat.

Permasalahan yang diamati pada petani perempuan di Desa Songan menurut pandangan feminisme adalah ketidaksetaraan upah antara petani perempuan dan petani laki-laki. Upah harian yang diberikan kepada petani laki-laki sebesar Rp.120.000,00 sedangkan upah harian yang diberikan kepada petani perempuan sebesar Rp.100.000,00. Namun petani perempuan tidak mempermasalahkan hal tersebut, karena selisih upah mereka tidak terlalu jauh. Petani laki-laki adalah kepala keluarga yang memiliki tanggung jawab yang lebih tinggi untuk menafkahi keluarga. Selain itu, pekerjaan berat di ladang pertanian dikerjakan oleh laki-laki jadi wajar jika upah laki-laki lebih besar daripada upah perempuan.

Ketika wawancara mengenai perasaan petani perempuan Desa Songan ketika diberikan beban ganda yaitu di ranah domestik dan ranah publik, mereka melakukannya karena kondisi atau keadaan. Suami yang hanya sebagai petani di ladang milik orang lain, dan upahnya kadang tidak bisa mencukupi kebutuhan hidup. Mereka memiliki beban ketika kebutuhan pangan tidak tercukupi, karena mereka yang bertanggungjawab terhadap pengadaan makanan di dalam keluarganya. Petani perempuan rata-rata hanya mengenyam pendidikan formal sampai sekolah dasar, sehingga ijazah yang mereka miliki tidak bisa digunakan untuk melamar kerja di tempat lain.

Beban ganda yang dipikul petani perempuan Desa Songan, tidak membuat mereka mengeluh karena sudah biasa menjalaninya. Bahkan mereka lebih memilih menerima beban ganda tersebut, dibandingkan hanya menunggu penghasilan dari suami. Mereka juga cukup dibantu oleh suami dan anak-anaknya dalam menyelesaikan tugas di rumah tangga. Terdapat kerja sama di dalam keluarga untuk memenuhi kebutuhan keluarga dan menyelesaikan tugas-tugas di rumah. Perempuan Songan yang bekerja sebagai petani adalah hal yang lumrah karena sebagian besar perempuan di sana memang ikut serta bekerja mencari nafkah. Mereka mampu mandiri dan memiliki kebebasan dalam bidang ekonomi yang membuat mereka mampu dihargai oleh keluarga dan masyarakat.

Petani perempuan di Desa Songan diberikan kesempatan dalam mengembangkan hobinya. Seperti penuturan dari ibu Ni Wayan Sarmi yang memiliki hobi memelihara ikan. Beliau diberikan fasilitas kolam oleh suaminya untuk memelihara ikan, dan itu juga dijadikan sebagai ladang bisnisnya. Namun, berbeda halnya dengan ibu Ni Komang Suarniti yang memiliki hobi menari. Beliau belum bisa mengembangkan hobinya karena terkendala waktu. Tetapi suaminya mengijinkan untuk melakukan hobinya.

\section{b. Pembahasan}

Berdasarkan dari hasil penelitian, terdapat empat faktor yang menyebabkan perempuan Songan terlibat dalam pertanian. Faktor -faktor tersebut yaitu faktor geografis, faktor desakan ekonomi, faktor kebiasaan, dan faktor pendidikan. Jenis pekerjaan yang digeluti masyarakat dipengaruhi oleh letak geografis. Letak geografis Desa Songan berada di kaki Gunung Batur dan tepi Danau Batur. Songan menjadi salah satu yang terkena dampak erupsi gunung Batur, sehingga tanahnya menjadi subur dan cocok untuk ditanami berbagai jenis tanaman. Hal ini yang menyebabkan sebagian besar masyarakat Songan berprofesi menjadi petani.

Perempuan Desa Songan bekerja sebagai seorang petani lebih banyak karena dorongan untuk membantu pekerjaan suaminya dan memenuhi kebutuhan keluarga. Hasil penelitian ini didukung dari penelitian Aswiyati (2016) yang mengungkapkan bahwa, perempuan yang terlibat dalam pertanian biasanya mereka tidak memiliki ladang sendiri dan menggarap ladang milik orang lain. Upah yang didapatkan dari menggarap ladang orang lain biasanya bernilai kecil sehingga petani laki-laki harus bekerja ekstra keras dan memerlukan keterlibatan perempuan agar dapat meningkatkan mekanisme pekerjaannya sehingga bisa memenuhi kebutuhan keluarga. Perempuan memiliki peran dalam rumah tangga namun mereka tetap ingin bekerja, sehingga perempuan memerlukan pekerjaan yang fleksibel agar dapat menyeimbangkan perannya. Perempuan memerlukan pekerjaan informal agar tidak meninggalkan perannya di ranah privat, dan salah satunya adalah dengan bekerja di sektor pertanian. Para perempuan terutama yang tinggal di pedesaan, turut ikut bekerja karena tuntutan faktor ekonomi (Arsanti, 2013). 
Perempuan di Desa Songan memilih menjadi seorang petani karena pekerjaan petani tidak membutuhkan pendidikan yang tinggi. Rata-rata mereka memiliki tingkat pendidikan sampai sekolah dasar dan ada pula yang tidak pernah mengenyam pendidikan formal dan mengalami buta huruf sehingga kesempatan kerjanya lebih kecil. Pekerjaan petani lebih banyak membutuhkan tenaga dibandingkan pikiran. Tingkat pendidikan memiliki keterkaitan terhadap peluang seseorang dalam memperoleh kesempatan kerja yang lebih baik. Ketika seseorang memperoleh kesempatan kerja yang lebih baik maka akan memperoleh gaji/pendapatan yang tinggi pula. Semakin tinggi pendapatan seseorang, maka tingkat kesejahteraannya juga akan semakin tinggi. Selain itu, kebiasaan dari kecil yang mewajibkan perempuan Songan untuk membantu keluarganya di ladang pertanian menjadi faktor berikutnya yang menyebabkan perempuan Songan menjadi petani. Mereka sudah mengetahui seluk beluk pertanian, dan keterampilan ini dimanfaatkan untuk mempertahankan hidupnya (Widyastuti, 2012)

Dorongan petani perempuan Desa Songan untuk mencukupi kebutuhan rumah tangga dan ada rasa tanggungjawab terhadap keluarga menyebabkan mereka bersemangat dalam menjalankan peran gandanya sebagai seorang petani maupun ibu rumah tangga. Penelitian ini juga didukung dengan hasil penelitian dari Fadilah (2018) yang mengungkapkan bahwa perempuan memiliki kesempatan yang sama di bidang ekonomi sehingga perempuan yang memiliki julukan tulang rusuk bergeser menjadi tulang punggung. Selain itu, penelitian dari Kartika (2017) yang mengungkapkan bahwa petani perempuan dan petani laki-laki memiliki tanggung jawab yang sama untuk memenuhi kebutuhan keluarga. Upah yang diberikan kepada petani relatif kecil, sehingga perempuan memiliki kewajiban untuk membantunya. Petani perempuan juga berkewajiban mengelola rumah tangga agar keluarganya aman, tentram, dan sejahtera. Mereka memiliki keterlibatan yang tinggi dalam mengupayakan kesejahteraan keluarganya. Perempuan mengurus rumah tangga, ikut serta dalam bekerja, dan mendidik anak-anaknya. Perempuan memiliki tingkat kreatifitas yang tinggi dalam menciptakan peluang usaha. Tingkat kesejahteraan keluarga yang tinggi memiliki dampak pada tingkat pendidikan anak-anak. Semakin baik kondisi ekonomi suatu keluarga, maka pendidikan anak akan terpenuhi dengan baik. Begitu juga bila kondisi ekonomi keluarga dan pendidikan anak terpenuhi dengan baik, maka akan tercapailah keluarga yang sejahtera (Astuti, 2013).

Secara tidak langsung, masyarakat Desa Songan sudah menerapkan nilai-nilai dalam ajaran feminisme. Petani perempuan diberikan kesempatan untuk bekerja dan mandiri secara ekonomi. Hal ini berkaitan dengan teori feminisme sosialis, perempuan memiliki hak mengembangkan diri di bidang ekonomi sehingga tidak memiliki ketergantungan dengan laki-laki. Perempuan yang bisa membiayai dirinya sendiri akan lebih bebas dari ketertindasan oleh laki-laki. Mereka juga diberi kesempatan untuk mengembangkan keterampilan melalui pelatihan yang diadakan dinas pertanian. Mereka juga cukup diapresiasi di dalam keluarga karena beban kerja mereka di rumah tangga turut diselesaikan oleh anggota keluarga lainnya. Artinya bahwa mental masyarakat terhadap perempuan sudah berubah, dan lebih menghargai perempuan (Rokhmansyah, 2016). Tantangan yang akan dihadapi untuk merealisasikan kesetaraan gender adalah merubah mental masyarakat dalam memandang sesuatu khususnya keadilan untuk perempuan. Ini membutuhkan jangka waktu yang panjang dan kekonsistenan masyarakat. Muara dari kesetaraan gender dalam skala mikro adalah mewujudkan kebahagiaan dalam keluarga yang akan nantinya melahirkan generasi-generasi bangsa yang hebat (Susanto, 2015).

Petani perempuan juga ikhlas dalam menjalani peran gandanya, yaitu pada ranah domestik dan ranah publik. Hasil penelitian ini juga didukung oleh penelitian dari Rahmawati (2015) yang mengemukakan bahwa Perempuan Bali memandang kerja sebagai suatu persembahan (yadnya) sehingga harus dilakukan secara tulus ikhlas tanpa memandang adanya ketidakseimbangan peran antara laki-laki. Kesetaraan gender dapat diamati dari kesempatan yang sama diperoleh perempuan dan laki-laki dalam mencapai hak-haknya seperti ikut berpatisipasi dalam kegiatan ekonomi, politik, sosial, dan budaya (Kartika \& Rabial Kanada, 2017)

\section{Simpulan dan Saran \\ a. Simpulan}

Berdasarkan rumusan masalah penelitian dan hasil data yang diperoleh peneliti, maka peneliti dapat menarik simpulan yaitu: perempuan Desa Songan bekerja sebagai seorang petani disebabkan karena empat faktor utama, yaitu faktor geografis, faktor desakan ekonomi, faktor kebiasaan, dan faktor pendidikan. Petani perempuan Desa Songan memiliki keterlibatan yang tinggi untuk menunjang kesejahteraan keluarganya. Dorongan petani perempuan Desa Songan untuk mencukupi kebutuhan rumah tangga dan ada rasa tanggung jawab terhadap keluarga menyebabkan mereka bersemangat dalam menjalankan peran gandanya sebagai seorang petani maupun ibu rumah tangga. Secara tidak langsung, masyarakat Desa Songan sudah menerapkan nilai-nilai dalam ajaran feminisme. Petani perempuan diberikan kesempatan untuk bekerja dan mandiri secara ekonomi. Mereka juga diberi kesempatan untuk 
mengembangkan keterampilan melalui pelatihan yang diadakan dinas pertanian. Mereka juga cukup diapresiasi di dalam keluarga karena beban kerja mereka di rumah tangga turut diselesaikan oleh anggota keluarga lainnya.

\section{b. Saran}

Berdasarkan dari kesimpulan, peneliti memberikan beberapa saran untuk masyarakat, perempuan, dan untuk penelitian lebih lanjut, yaitu: bagi masyarakat perlu adanya kegiatan pemberdayaan keluarga untuk menerapkan kesetaraan gender sehingga keharmonisan keluarga dapat tercapai. Bagi perempuan sebaiknya berusaha untuk mampu mandiri secara ekonomi agar tidak mengalami penindasan terutama dari laki-laki. Bagi peneliti selanjutnya yang ingin meneliti tema yang sama sebaiknya menggunakan sudut pandang yang berbeda untuk lebih memperkaya ilmu pengetahuan.

\section{Daftar Pustaka}

Anwar, N. (2013). Organisasi Perempuan dan Pembangunan Kesejahteraan. Jurnal Sosiologi Reflektif, 8(1). Arjani, N. L. (2007). Feminisasi Kemiskinan dalam Kultur Patriarki. Jurnal Studi Gender Srikandi, 6(1), 110. https://ojs.unud.ac.id/index.php/srikandi/article/download/2878/2052

Arsanti, T. A. (2013). Perempuan dan Pembangunan Sektor Pertanian. Jurnal Maksipreneur: Manajemen, Koperasi, Dan Entrepreneurship, 3(1), 63. https://doi.org/10.30588/jmp.v3i1.88

Astuti, T. (2011). Kontruksi Gender dalam Realitas Sosial. UNNES Press.

Djoharwinarlien, S. (2012). Dilema Kesetaraan Gender Refleksi dan Respon Praktis. Center for Politics and Goverment.

Fadilah, S. (2018). Kesetaraan gender : Fenomena pergeseran peran ekonomi wanita dari tulang rusuk menjadi tulang punggung. Gender Dan Anak, 1(1), 18-26.

Hanum, S. L. (2017). Peran Ibu Rumah Tangga dalam Membangun Kesejahteraan Keluarga. Journal Of Multidispliner Studies, 1(2).

Indrayani, L., \& Musmini, L. S. (2020). The Meaning of Economic Activity in the Family Economics from Balinese Wome n's Perspective. 394(Icirad 2019), 127-132.

Kartika, Q., \& Rabial Kanada. (2017). Peran Ganda Perempuan pada Keluarga Masyarakat Petani: Kasus Istri Petani di kecamatan Merapi Selatan Kabupaten Lahat. An Nisa'a: Jurnal Kajian Gender Dan Anak, 12, 151-162. http://jurnal.radenfatah.ac.id/index.php/annisa/article/view/1786

Lubis, A. Y. (2015). Pemikiran Kritis Kontemporer Dari Teori Kritis, Culture, Studies, Feminisme, Postkolonial Hingga Multikulturalisme. Pt RajaGrafindo Persada.

Rokhmansyah, A. (2016). Pengantar Gender dan Feminisme. Penerbit Garudhawaca.

Safira, D. (2019). Membunuh Hantu Hantu Patriarki. CV Jalan Baru.

Susanto, N. H. (2015). Tantangan Mewujudkan Kesetaraan Gender dalam Budaya Patriarki. Jurnal Muwazah, 7(2), 120-130.

Widyastuti, A. (2012). Analisis Hubungan Antara Produktivitas Pekerja dan Tingkat Pendidikan Pekerja Terhadap Kesejahteraan Keluarga di Jawa Tengah Tahun 2009. Economic Development Analysis Journal, 1(2).

Yusuf, M. (2014). Metode Penelitian Kuantitatif, Kualitatif, dan Penelitian Gabungan. Prenad. 